\title{
Rapid Crystallization of Chemically Synthesized Hammerhead RNAs using a Double Screening Procedure
}

\author{
William G. Scott ${ }^{*}$, John T. Finch, Richard Grenfell, Jan Fogg \\ Terry Smith, Michael J. Gait and Aaron Klug
}

\author{
MRC Laboratory of Molecular \\ Biology, Hills Road \\ Cambridge, $\mathrm{CB} 2 \mathrm{Q} \mathrm{QH}$ \\ England
}

\begin{abstract}
To find conditions for obtaining diffraction-quality crystals of a hammerhead RNA rapidly and reproducibly, we employed a "double screening" procedure in which we screened six different RNA synthetic constructs against 48 crystallization conditions using a newly devised sparse matrix. We obtained crystals immediately and diffraction-quality crystals of the sixth RNA construct within six months of initiating the screening of additional RNA sequences. The best crystals diffract to $2.9 \AA$ resolution when flashcooled at synchrotron X-ray sources. Solid-support chemical synthesis combined with sparse matrix screening should allow rapid production of diffraction-quality crystals of a variety of small RNAs, reducing the time commitment for initiating such crystallography projects from several years to several months. The synthetic approach also makes introduction of modified bases to prevent self-cleavage and to generate isomorphous heavy-atom derivative crystals a rapid and straightforward process.
\end{abstract}

Keywords: hammerhead RNA; RNA structure; crystallization screen; RNA crystallization; catalytic RNA mediate (or transition state) as shown in Figure 1. An additional general acid catalyst may act by protonating the 5'-oxygen leaving group at the cleavage site. The final products of the cleavage reaction have 5'-hydroxyl and 2',3'-cyclic phosphate termini at the cleavage site.

In order to obtain a detailed understanding of how the hammerhead RNA conformation activates a highly sequence-specific strand cleavage reaction, it will be necessary to determine the three-dimensional structure of a hammerhead RNA with the catalytic metal bound to the active site. Previously, crystals of a hammerhead RNA bound to a DNA substrate (Pley et al., 1993, 1994) and a hammerhead RNA containing a mutation in the absolutely conserved core region (Kim et al., 1994) have been reported. Our approach differs in that we have crystallized a hammerhead RNA having a minimal structural perturbation; we have replaced the 2'-hydroxyl of the cytosine at the cleavage site with a 2'-methoxyl group in an otherwise unaltered RNA, using solid-phase oligoribonucleotide phosphoramidite chemical synthesis (Gait et al., 1991) to produce the entire hammerhead RNA constructs used for crystallization experiments.

Using the chemical synthesis approach, we were able to screen six different hammerhead RNA constructs (depicted in Figure 2) for crystallization
Abbreviations used: PEG, polyethylene glycol; OAc, acetate; MPD, 2-methyl-2,4-pentanediol. 


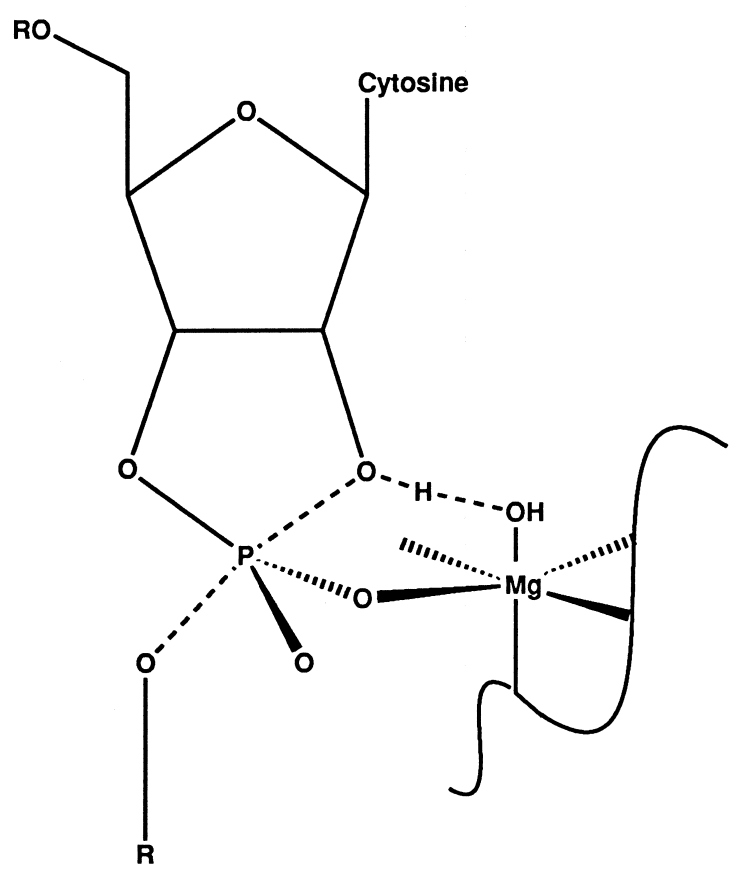

Figure 1. A putative structure of the reaction intermediate or transition state involved in hammerhead RNA self-cleavage (Dahm et al., 1993). In this mechanism, magnesium hydroxide is believed to mediate both basecatalysed and acid-catalysed formation of the 2',3'-cyclic pentaco-ordinated phosphate intermediate or transition state, although such a reaction could involve more than one magnesium ion. The hydroxyl bound to the metal abstracts the 2 ' proton, initiating nucleophilic attack at the phosphorus atom. In the mechanism shown, direct coordination of the metal ion to the pro- $\mathrm{R}_{\mathrm{p}}$ oxygen allows the metal to act as a Lewis acid catalyst. An additional general acid catalyst, not shown, may act by donating a proton to the leaving 5'-oxygen.

conditions fairly rapidly (in six months) to find the best sequences suitable for X-ray analysis. This represents a major reduction in the time usually required for production of diffraction-quality RNA crystals. We report here the hammerhead RNA sequences we have synthesized, the crystallization screening conditions we developed to test each RNA construct, and the final crystallization conditions for the most promising hammerhead RNA construct which forms trigonal crystals that diffract to $2.9 \AA$ resolution. Complete chemical synthesis of the hammerhead ribozyme has also enabled us to obtain heavy-atom (bromo-deoxyuracil) isomorphous derivatives almost immediately, from which we have now solved the structure (Scott et al., 1995).

\section{Results and Discussion}

Crystals of RNA constructs 1, 2, 3, and 6 were obtained under the conditions listed in Table 1. Of these, RNA 1 and RNA 6 yielded the most promising crystals. The optimized crystals of RNA 1 were grown by vapour diffusion in $4 \mu \mathrm{l}$ hanging drops at $30^{\circ} \mathrm{C}$ in a reservoir of $25 \%$ hexane-1,6-diol, $2 \%(\mathrm{w} / \mathrm{v})$
PEG 200, $10 \mathrm{mM} \mathrm{MgCl}_{2}, 0.25 \mathrm{M} \mathrm{KCl}, 50 \mathrm{mM}$ sodium cacodylate $(\mathrm{pH}$ 6.5). These crystals were rhomboidal prisms $0.3 \mathrm{~mm}$ in the longest dimension and were not characterized further. The best RNA crystals were of RNA 6, which grew as large as $0.5 \mathrm{~mm} \times 0.5 \mathrm{~mm} \times 1.0 \mathrm{~mm}$ rhomboidal prisms and diffracted anisotropically to $2.9 \AA$ resolution. These were grown in sitting drop Microbridges (obtained from Crystal Microsystems, UK) in $10 \mu \mathrm{l}$ to $20 \mu \mathrm{l}$ drops by vapour diffusion. The reservoir solution, containing $5 \%(\mathrm{v} / \mathrm{v})$ glycerol, $21 \%$ to $25 \%$ PEG 4000 or $6000,100 \mathrm{mM} \mathrm{NH}_{4} \mathrm{OAc}, 10 \mathrm{mM} \mathrm{Mg}(\mathrm{OAc})_{2}$ and $50 \mathrm{mM}$ ammonium cacodylate $(\mathrm{pH}$ 6.5) was mixed thoroughly with an equal volume of a previously annealed $0.5 \mathrm{mM}$ RNA solution containing $10 \mathrm{mM}$ ammonium cacodylate ( $\mathrm{pH}$ 6.5), and $1 \mathrm{mM}$ spermine. Crystals formed spontaneously within 48 hours or were seeded, and grew to full size within two weeks. The crystals were found to be highly radiation-sensitive and flash cooling at $100 \mathrm{~K}$ in the reservoir solution containing $20.0 \%$ glycerol was necessary to preserve diffraction. Several $3.1 \AA$ resolution native data sets have been collected at Brookhaven National Laboratory and at Daresbury Laboratory synchrotron facilities. The best of these has an $R_{\text {(merge) }}$ of $8.1 \%$ and is $98 \%$ complete to $3.1 \AA$ resolution. In addition, we have obtained crystals of two 5-bromo-deoxyuracil isomorphous derivatives under the same crystallization conditions, and have collected anomalous differences data sets on these at Daresbury. These data sets have allowed us to determine the space group and cell dimensions of the crystals to be $P 3_{1} 21$ and $a=b=65.3 \AA$, $c=138.1 \AA$, respectively, and to produce an interpretable electron density map which has enabled us to solve the structure of the hammerhead RNA with a 2'-O-methylcytosine in the active site (Scott et al., 1995).

\section{Screening of crystallization conditions}

We devised a sparse matrix screen for RNA crystallization inspired by a similar set of conditions for proteins (Jancarik \& Kim, 1991). Subsequent to this another such screen was published (Doudna et al., 1993) which differs most substantially in that it makes more use of small organic precipitating agents such as those found useful for tRNA and less use of different molecular weight PEGs. Most of our crystals formed in polyethylene glycol/monovalent salt mixed precipitating agent, conditions not found in the latter screen. Polyethylene glycol/monovalent salt mixed precipitating agent conditions have been useful for crystallizing several different sequences of hammerhead RNAs including those reported by Pley et al. (1993), as well as other RNA sequences in our laboratory and elsewhere (Holbrook et al., 1991; Baeyens et al., 1994). In general we recommend that either of these sparse matrix screens be used, but suggest that a number of polyethylene glycol/ monovalent salt mixed precipitating agent conditions be tested. In our experience varying the sequence of the RNA is probably more important 


\section{Hammerhead RNA synthetic constructs screened for crystallization}
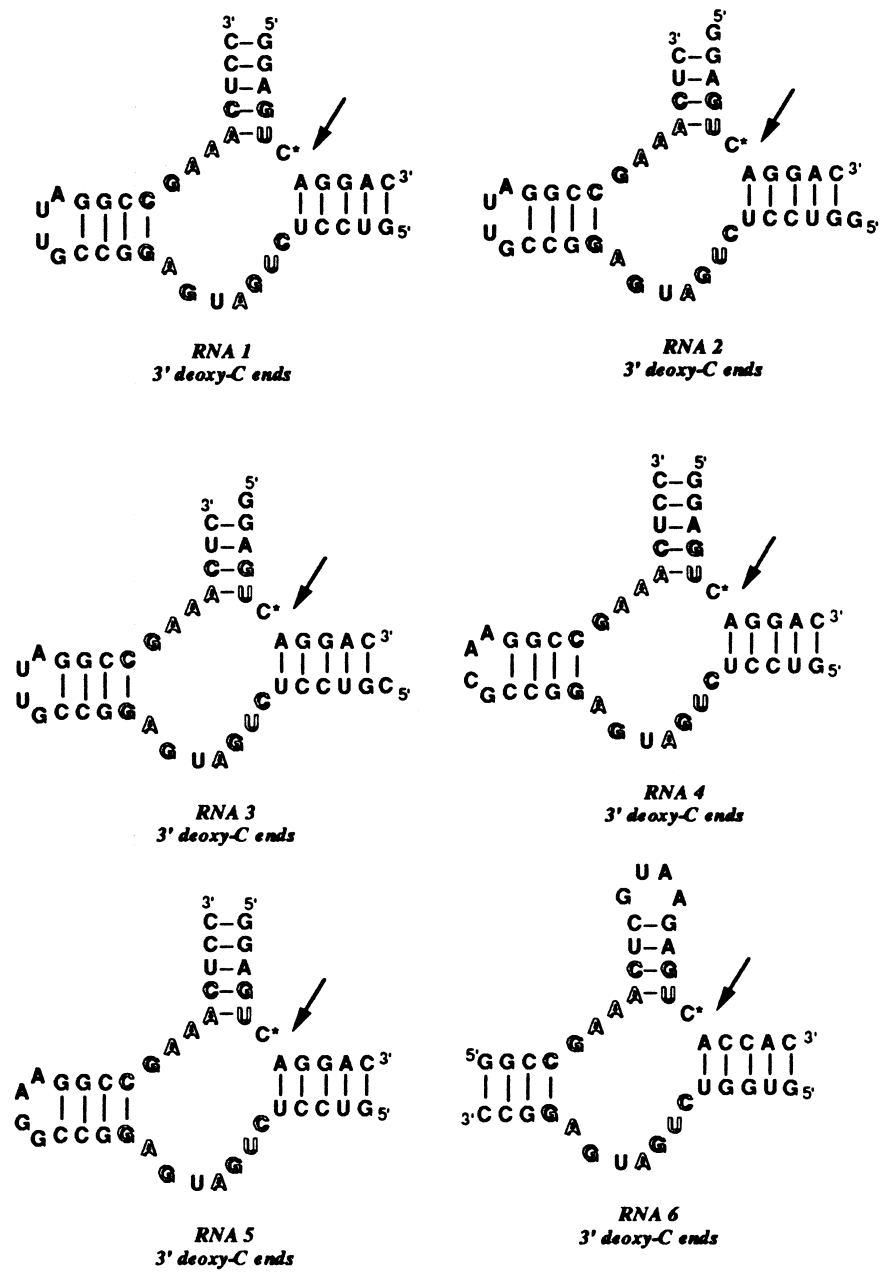

$C^{*}=2$ MeOC

Figure 2. The six RNA synthetic constructs screened to find the most useful RNA crystals. The conserved nucleotides essential for catalytic cleavage are depicted as outlined letters. The arrows denote selfcleavage sites. Each of the RNA strands was synthesized on a deoxycytosine support, which significantly increased synthetic yield. RNAs 2 and 3 have 5 ' overhangs. RNAs 4 and 5 contain sequence variations in the tetraloop region, and RNA 6 has a tetraloop removed from stem I and added to stem II, in addition to some further sequence changes to minimize the likelihood of alternative conformations forming within each strand. than finding a "magic bullet" crystallization condition in a sparse-matrix search; RNAs tend to crystallize under several different conditions or else none.

\section{Design of the hammerhead RNA constructs}

Six hammerhead RNA constructs, each consisting of an "enzyme" strand and a "substrate" strand containing the cleavage site, were designed sequen- tially to test for crystallization. These are illustrated in Figure 2. Each of these RNA constructs contains a 2'-O-methylcytosine in the active site of the substrate strand to inhibit cleavage, and each strand contains deoxyribocytosine 3 ' ends (as the synthetic yield on deoxy-solid supports was much higher). The first five constructs contain an 11 nucleotide "substrate" with a 2'-O-methylcytosine at the cleavage site, and a 32 nucleotide "enzyme" strand. These sequences are

Table 1. RNA crystal constructs 1 to 6

\begin{tabular}{|c|c|c|}
\hline RNA construct & Best crystals obtained & Description of initial crystal quality \\
\hline 1 & Conditions $13,24,34$ and 44 & Approximately $0.05 \times 0.05 \times 0.1 \mathrm{~mm}$ plates \\
\hline 2 & Conditions 7 and 18 & Approximately $0.1 \times 0.1 \times 0.1 \mathrm{~mm}$ prisms \\
\hline 3 & Conditions $5,7,12$ and 31 & Approximately $0.1 \times 0.1 \times 0.1 \mathrm{~mm}$ prisms \\
\hline 4 & No crystals & \\
\hline 5 & No crystals & \\
\hline 6 & Conditions 41,43 & $\begin{array}{l}0.1 \times 0.2 \times 0.2 \mathrm{~mm} \text { rhomboid prisms, optimized to } \\
0.5 \times 0.5 \times 1.0 \mathrm{~mm} \text { trigonal crystals which diffract to } 2.9 \AA \\
\left(\text { Space group } P 3_{1} 21, a=b=65 \AA, c=138 \AA\right)\end{array}$ \\
\hline & and 45 & $\begin{array}{l}0.3 \times 0.3 \times 1.0 \mathrm{~mm} \text { hexagonal crystals which diffract to } 3.1 \AA \\
\text { (Space group } P 6_{1} 22, a=b=63 \AA, c=140 \AA \text { ) }\end{array}$ \\
\hline
\end{tabular}


Table 2. RNA crystallization sparse matrix

\begin{tabular}{|c|c|c|}
\hline $\mathrm{pH}, 50 \mathrm{mM}$ buffer & Precipitating agent & Salts and additives \\
\hline 1. 6.0, Cacodylate & $5 \% \mathrm{MPD}$ & $40 \mathrm{mM} \mathrm{MgCl}{ }_{2}$ \\
\hline 2. $5.6, \mathrm{Mes}$ & 5\% PEG 8000 & $200 \mathrm{mM} \mathrm{KCl}+10 \mathrm{mM} \mathrm{MgCl}_{2}$ \\
\hline 3. 6.0 , Cacodylate & $1.0 \mathrm{M} \mathrm{Li}_{2} \mathrm{SO}_{4}$ & $10 \mathrm{mM} \mathrm{MgCl}_{2}$ \\
\hline 4. 6.0, Mes & $15 \%$ Isopropanol & $20 \mathrm{mM} \mathrm{MgCl}{ }_{2}$ \\
\hline 5. 7.0, Hepes & $1.6 \mathrm{M}\left(\mathrm{NH}_{4}\right)_{2} \mathrm{SO}_{4}$ & $10 \mathrm{mM} \mathrm{MgCl}_{2}+0.2 \mathrm{mM} \mathrm{Co}\left(\mathrm{NH}_{3}\right)_{6} \mathrm{Cl}_{3}$ \\
\hline 6. 5.6, Mes & $10 \%$ PEG 400 & $10 \mathrm{mM} \mathrm{MgSO}_{4}+200 \mathrm{mM} \mathrm{KCl}$ \\
\hline 7. 6.0, Cacodylate & $1.7 \mathrm{M}\left(\mathrm{NH}_{4}\right)_{2} \mathrm{SO}_{4}$ & $15 \mathrm{mM} \mathrm{Mg}(\mathrm{OAc})_{2}$ \\
\hline 8. 7.5 , Tris & $5 \%$ Isopropanol & $10 \mathrm{mM} \mathrm{MgCl}{ }_{2}$ \\
\hline 9. 6.5, Cacodylate & 10\% PEG 4000 & $200 \mathrm{mM} \mathrm{KCl}+10 \mathrm{mM} \mathrm{MgCl}_{2}$ \\
\hline 10. 7.0, Hepes & $15 \% \mathrm{MPD}$ & $5 \mathrm{mM} \mathrm{MgSO}_{4}$ \\
\hline 11. $6.0, \mathrm{Mes}$ & 5\% PEG 4000 & $5 \mathrm{mM} \mathrm{MgSO}_{4}$ \\
\hline 12. 5.6 , Mes & $20 \%$ MPD & $100 \mathrm{mM} \mathrm{Mg}(\mathrm{OAc})_{2}$ \\
\hline 13. 6.5 , Cacodylate & $15 \%$ PEG 400 & 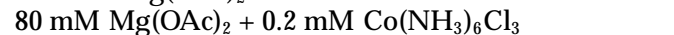 \\
\hline 14. 7.5 , Tris & 10\% PEG 4000 & $200 \mathrm{mM} \mathrm{KCl}+50 \mathrm{mM} \mathrm{MgCl}_{2}$ \\
\hline 15. 7.5 , Tris & $1.6 \mathrm{M}\left(\mathrm{NH}_{4}\right)_{2} \mathrm{SO}_{4}$ & $10 \mathrm{mM} \mathrm{MnCl}_{2}$ \\
\hline 16. 7.0, Hepes & $5 \%$ PEG 8000 & $20 \mathrm{mM} \mathrm{MgCl}_{2}$ \\
\hline 17. 6.5, Cacodylate & $10 \%$ Isopropanol & $150 \mathrm{mM} \mathrm{Mg}(\mathrm{OAc})_{2}+0.2 \mathrm{mM} \mathrm{Co}\left(\mathrm{NH}_{3}\right)_{6} \mathrm{Cl}_{3}$ \\
\hline 18. 6.5, Cacodylate & $1.3 \mathrm{M} \mathrm{Li}_{2} \mathrm{SO}_{4}$ & 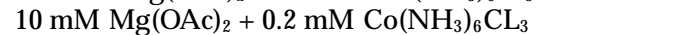 \\
\hline 19. 7.5 , Tris & $10 \% \mathrm{MPD}$ & $10 \mathrm{mM} \mathrm{MgCl}_{2}$ \\
\hline 20. 5.6, Mes & $1.1 \mathrm{M} \mathrm{Li}_{2} \mathrm{SO}_{4}$ & $10 \mathrm{mM} \mathrm{MgCl}_{2}$ \\
\hline 21. 7.0, Hepes & 5\% PEG 400 & $100 \mathrm{mM} \mathrm{KCl}+10 \mathrm{mM} \mathrm{MgCl} 2$ \\
\hline 22. 7.0, Hepes & 5\% PEG 4000 & $200 \mathrm{mM} \mathrm{NH}_{4} \mathrm{OAc}+150 \mathrm{mM} \mathrm{Mg}(\mathrm{OAc})_{2}$ \\
\hline 23. 6.5, Cacodylate & 10\% PEG 8000 & $100 \mathrm{mM} \mathrm{Mg}(\mathrm{OAc})_{2}+200 \mathrm{mM} \mathrm{KCl}$ \\
\hline 24. 6.0, Mes & $10 \%$ PEG 400 & $100 \mathrm{mM} \mathrm{KCl}+10 \mathrm{mM} \mathrm{MgCl} 2$ \\
\hline 25. 7.0, Hepes & 25\% Dioxane & $5 \mathrm{mM} \mathrm{MgCl}{ }_{2}$ \\
\hline 26. 6.0, Cacodylate & $15 \%$ Isopropanol & $5 \mathrm{mM} \mathrm{MgCl}_{2}+2 \mathrm{mM} \mathrm{CoCl}_{2}$ \\
\hline 27. 7.5 , Tris & 10\% Dioxane & $5 \mathrm{mM} \mathrm{MgCl}_{2}$ \\
\hline 28. 5.6, Mes & 20\% PEG 8000 & $10 \mathrm{mM} \mathrm{MgCl}_{2}+100 \mathrm{mM}\left(\mathrm{NH}_{4}\right)_{2} \mathrm{SO}_{4}$ \\
\hline 29. 6.0, Cacodylate & $10 \%$ PEG 4000 & $200 \mathrm{mM} \mathrm{KCl}+10 \mathrm{mM} \mathrm{CaCl}_{2}$ \\
\hline 30. 7.0, Hepes & 10\% PEG 400 & $200 \mathrm{mM} \mathrm{KCl}+5 \mathrm{mM} \mathrm{CdSO}_{4}$ \\
\hline 31. 6.5, Cacodylate & 10\% PEG 4000 & $200 \mathrm{mM} \mathrm{NH}_{4} \mathrm{OAc}+10 \mathrm{mM} \mathrm{CaCl}_{2}$ \\
\hline 32. 7.5, Tris & 5\% PEG 8000 & $100 \mathrm{mM} \mathrm{KCl} 5 \mathrm{mM} \mathrm{CdSO}_{4}$ \\
\hline 33. 6.0, Cacodylate & $30 \% \mathrm{MPD}$ & $40 \mathrm{mM} \mathrm{MgOAc}_{2}$ \\
\hline 34. 7.0, Hepes & 10\% PEG 400 & $100 \mathrm{mM} \mathrm{KCl}+10 \mathrm{mM} \mathrm{CaCl}_{2}$ \\
\hline 35. 7.0, Hepes & $20 \%$ Hexane diol & $200 \mathrm{mM} \mathrm{KCl}+10 \mathrm{mM} \mathrm{MgCl}_{2}$ \\
\hline 36. 7.5 , Tris & $20 \%$ Hexane diol & $5 \mathrm{mM} \mathrm{CdSO}_{4}$ \\
\hline 37. 6.5, Cacodylate & $10 \%$ Hexane diol & $0.1 \mathrm{mM} \mathrm{Co}\left(\mathrm{NH}_{3}\right)_{6} \mathrm{Cl}_{3}+5 \mathrm{mM} \mathrm{MgCl} 2$ \\
\hline 38. 5.6, Mes & 10\% PEG 2000 & $200 \mathrm{mM} \mathrm{KCl}+10 \mathrm{mM} \mathrm{MgCl} 2+0.2 \mathrm{mM} \mathrm{Co}\left(\mathrm{NH}_{3}\right)_{6} \mathrm{Cl}_{3}$ \\
\hline 39. 8.0, Tris & 5\% PEG 2000 & $200 \mathrm{mM} \mathrm{KCl}+10 \mathrm{mM} \mathrm{MgCl}{ }_{2}$ \\
\hline 40. 6.0, Cacodylate & $30 \%$ PEG 4000 & $200 \mathrm{mM} \mathrm{NH}_{4} \mathrm{Cl}+10 \mathrm{mM} \mathrm{CaCl}_{2}$ \\
\hline 41. 6.5 , Cacodylate & $30 \%$ PEG 4000 & $80 \mathrm{mM} \mathrm{MgOAc}$ \\
\hline 42. 7.0, Hepes & $30 \%$ Hexane diol & $200 \mathrm{mM} \mathrm{NH}{ }_{4} \mathrm{Cl}+10 \mathrm{mM} \mathrm{MgCl}{ }_{2}$ \\
\hline 43. 6.5, Cacodylate & $30 \%$ PEG 8000 & $200 \mathrm{mM} \mathrm{NH}_{4} \mathrm{OAc}+10 \mathrm{mM} \mathrm{Mg}(\mathrm{OAc})_{2}$ \\
\hline 44. 8.5, Tris & $30 \%$ PEG 400 & $100 \mathrm{mM} \mathrm{KCl}+10 \mathrm{mM} \mathrm{MgCl}_{2}$ \\
\hline 45. 6.0, Cacodylate & $1.8 \mathrm{M} \mathrm{Li}_{2} \mathrm{SO}_{4}$ & $10 \mathrm{mM} \mathrm{MgSO}_{4}$ \\
\hline 46. 7.0, Hepes & $1.6 \mathrm{M} \mathrm{Li}_{2} \mathrm{SO}_{4}$ & $50 \mathrm{mM} \mathrm{MgSO}_{4}$ \\
\hline 47. 6.5, Cacodylate & $2.0 \mathrm{M}\left(\mathrm{NH}_{4}\right)_{2} \mathrm{SO}_{4}$ & $10 \mathrm{mM} \mathrm{MgSO}_{4}$ \\
\hline 48. 8.5 , Tris & $1.8 \mathrm{M}\left(\mathrm{NH}_{4}\right)_{2} \mathrm{SO}_{4}$ & $25 \mathrm{mM} \mathrm{MgSO}_{4}$ \\
\hline
\end{tabular}

closely related to a hammerhead RNA enzyme previously characterized as having standard MichaelisMenten kinetics (Fedor \& Uhlenbeck, 1990) and all have a tetraloop on stem II. Sequences 2 and 3 have one-base overhangs on stems I and III with the hope of facilitating end of helix interactions similar to those found in crystals of DNA-protein complexes (Schultz et al., 1990). Sequences 4 and 5 has the tetraloop base sequence changed with the hope of altering crystal packing. Sequence 6 has the tetraloop moved from stem II to stem III to make a 16 nucleotide "enzyme" strand and 25 nucleotide "substrate" strand incorporating a 2'-O-methylcytosine in the active site. This final sequence yielded the best crystals.

\section{Screening of RNA sequences}

About $50 \%$ of our time was devoted initially to optimizing the crystallization conditions first ob- tained from RNA construct 1 by altering precipitating agents, buffers, salts, and the temperature at which the crystals were grown. However, improvements in crystal quality were only incremental and the optimized crystals were grown under rather unusual conditions $\left(30^{\circ} \mathrm{C}, 25 \%\right.$ hexane-1,6-diol, $2 \%$ PEG 200). We then realized that varying the sequence of the RNA might lead to more pronounced improvements in crystal quality than varying the crystallization conditions was likely to do. We therefore designed RNA constructs 2 to 6 and screened each of these using the 48 crystallization conditions reported in Table 2. The first crystals obtained in the screen of RNA 6 were of a higher quality than the crystals of RNA 1 which had been "optimized" for five months, indicating that our efforts should be focused on this construct. Although crystals of RNA 2 and RNA 3 formed under conditions different from those of RNA 1, the crystals of these RNAs were not 
significantly improved compared to those of RNA 1. RNAs 4 and 5 did not crystallize at all, indicating that RNA sequences in the tetraloops may be important for mediating (or in this case disrupting) crystal contacts. It is possible, however, that RNA 6 is simply more stable as an "enzyme-substrate" complex than RNAs 1 to 5 . We initially chose the 32-mer plus 11-mer complex because it displayed Michaelis-Menten kinetics (Fedor \& Uhlenbeck, 1990). Constructs similar to RNA 6, however, display "burst-lag" kinetics characteristic of enzymes which are product-dissociation limited (Uhlenbeck, 1987; Fedor \& Uhlenbeck, 1990). In retrospect this adhesiveness of the ribozyme with respect to the products of cleavage may be advantageous in that the same forces would likely contribute to the added stability of the complex of the "enzyme" strand of RNA 6 with the modified substrate which essentially acts as a competitive inhibitor complex. Thus, changing the length in addition to the connectivity of RNA constructs should change their crystallization behavior. Further changes in the ends of RNA 6 will be made in an attempt to improve the diffraction quality of the crystal while we attempt to solve the structure with the current crystals and their isomorphous derivatives.

\section{Characterization of RNA 6 crystals}

The best crystals were obtained from construct RNA 6 and were rhombus-shaped prisms up to $0.5 \mathrm{~mm} \times 0.5 \mathrm{~mm} \times 1.0 \mathrm{~mm}$ in size. The crystals are trigonal with space group $P 3_{1} 21$ and unit cell $a=b=65.3 \AA, c=138.1 \AA$. The crystals diffract anisotropically to $2.9 \AA$ resolution in an intense synchrotron-generated X-ray beam when flashcooled in a glycerol solution at $100 \mathrm{~K}$. The strongest diffraction is observed in the $c^{*}$ direction, which is approximately parallel to the helical axes of the RNA in the crystal. The crystals can be obtained only from PEG solutions equal to or greater than 4000 in molecular weight, and the presence of ammonium ion tends to encourage the crystals to grow as thick prisms rather than as thin plates. The crystals grow best at $20^{\circ} \mathrm{C}$ and not at all at $4^{\circ} \mathrm{C}$. Complete mixing of the viscous crystallization solution is absolutely critical to prevent immediate spurious nucleation and "showering" of microcrystals; addition of up to $5 \%$ glycerol helps to prevent spurious nucleation but larger amounts of glycerol inhibit crystallization completely. At least two isomorphous derivative crystals have been grown under the same conditions using RNAs which have had 5-bromo-deoxyuracil substituted in place of one of the uracil groups in the double-stranded regions. Both of the derivatives each revealed two sites in the asymmetric unit of isomorphous difference and anomalous difference Patterson maps, suggesting that the asymmetric unit of the crystal is a dimer. We have now solved the structure of this dimer of hammerhead ribozymes to $3.1 \AA$ resolution, and will report the structure in a subsequent communication (Scott et al., 1995).

\section{Conclusions}

RNA crystallization is generally considered to be a difficult undertaking because of the time consumed preparing samples and finding appropriate crystallization conditions. By screening both a wide variety of crystallization conditions and RNA sequences it is possible to converge upon a sequence and crystallization condition for producing large diffraction-quality crystals fairly rapidly. The use of solid-support ribonucleotide phosphoramidite synthesis has enabled us to test several sequences of hammerhead ribozyme RNA within a period of a few months, and has the added advantage of allowing incorporation of modified bases and heavy atoms for producing cleavage-arrested and isomorphous derivative ribozyme crystals in a very straightforward manner. We believe that this methodology will be of general interest to those who wish to produce diffraction-quality crystals of small RNAs rapidly.

\section{Experimental}

\section{RNA synthesis and preparation}

Each of the RNA strands was synthesized using oligoribonucleotide phosphoramidite chemistry, incorporating a 2'-O-methylcytosine in the active site of the "substrate" RNA strands. The RNA was synthesized from Glen Research ribonucleoside phosphoramidites purchased from Cambio and assembled on an Applied Biosystems 380 B solid phase oligonucleotide synthesizer on 1, 5 or $10 \mu \mathrm{mol}$ scales and deprotected using methanolic ammonia and tetrabutylammonium fluoride as described (Gait et al., 1991). The de-salted crude RNA was then purified on $15 \%$ or $20 \%(\mathrm{w} / \mathrm{v})$ polyacrylamide $8 \mathrm{M}$ urea denaturing gels run at $37 \mathrm{~W}$, electroeluted, and dialysed extensively first against salt $\left(1 \mathrm{M} \mathrm{NaCl}\right.$ or $\left.\mathrm{NH}_{4} \mathrm{OAc}\right)$ and then pure water. Finally, the RNA was lyophilized, and redissolved to a concentration of $0.5 \mathrm{mM}$ of enzyme plus substrate strands in $10 \mathrm{mM}$ cacodylate buffer (pH 6.5), $1 \mathrm{mM}$ spermine. Prior to crystallization, the RNA enzyme-substrate complex was heated to $75^{\circ} \mathrm{C}$ and slow-cooled in a heat block to room temperature.

\section{RNA crystallization}

A sparse matrix of 48 RNA crystallization conditions was developed for crystallizing the synthetic hammerhead RNA constructs (as well as other RNAs and RNA-protein complexes) by patterning it after a similar screen developed for proteins (Jancarik \& Kim, 1991). Our screen relies quite heavily on polyethylene glycols of several different molecular weights, many in combination with monovalent salts, as precipitating agents, and thus differs from an RNA crystallization screen subsequently published based on tRNA crystallization conditions (Doudna et al., 1993). The 48 conditions are listed in Table 2 . The crystallization conditions were screened using the hanging drop method. A $4 \mu \mathrm{l}$ drop of the solution, previously heated to $75^{\circ} \mathrm{C}$ and annealed, containing $2 \mu \mathrm{l}$ of $0.5 \mathrm{mM}$ hammerhead RNA in $1 \mathrm{mM}$ spermine, $10 \mathrm{mM}$ cacodylate buffer $(\mathrm{pH} 6.5)$ was mixed with $2 \mu \mathrm{l}$ of the reservoir solution described in Table 2. The drops were each suspended on $22 \mathrm{~mm}$ siliconized microscope cover slips over $0.75 \mathrm{ml}$ aliquots of the same reservoir solution placed in each of the wells of 
two 24-well Linbro tissue culture plates. The cover glasses were sealed to the well rims with vacuum grease, and the crystallizations were allowed to equilibrate at $20^{\circ} \mathrm{C}$ and were inspected daily for crystal formation. In almost all cases in which crystals appeared, they did so within two or three days.

\section{Acknowledgements}

We thank Stephen Price, Chris Oubridge, Jane Grasby, Kiyoshi Nagai and Linda Chapman for advice and help with RNA synthesis, purification and crystallization. W. G. S. thanks the American Cancer Society for a postdoctoral fellowship (grant number PF-3970).

\section{References}

Baeyens, K. J., Jancarik, J. \& Holbrook, S. R. (1994). Use of low-molecular-weight polyethylene glycol in the crystallization of RNA oligomers. Acta Crystallog. sect. $D, \mathbf{5 0}, 764-767$.

Dahm, S. \& Uhlenbeck, O. C. (1991). Role of divalent metal ions in the hammerhead RNA cleavage reaction. Biochemistry, 30, 9464-9469.

Dahm, S., Derrick, W. B. \& Uhlenbeck, O. C. (1993). Evidence for the role of solvated metal hydroxide in the hammerhead cleavage mechanism. Biochemistry, 32, 13040-13045.

Doudna, J. A., Grosshans, C., Gooding, A. \& Kundrot, C. E. (1993). Crystallization of ribozymes and small RNA motifs by a sparse matrix approach. Proc. Natl Acad. Sci. USA, 90, 7829-7833.

Fedor, M. J. \& Uhlenbeck, O. C. (1990). Substrate sequence effects on hammerhead RNA catalytic efficiency. Proc. Natl Acad. Sci. USA, 87, 1668-1672.

Gait, M. J., Pritchard, C. \& Slim, G. (1991). Oligoribonucleotide synthesis. In Oligonucleotide Synthesis, A Practical Approach (Eckstein, F., ed.), Practical Approach Series, Oxford University Press, Oxford, UK.

Holbrook, S. R., Cheong, C., Tinoco, I., Jr, Kim, S.-H. (1991). Crystal structure of an RNA double helix incorporating a track of non-Watson-Crick base pairs. Nature, 353, 579-581.

Jancarik, J. \& Kim, S.-H. (1991). Sparse matrix sampling: a screening method for crystallization of proteins. J. Appl. Crystallog. 24, 409-411.

Kim, R., Holbrook, E. L., Jancarik, J., Pandit, J., Weng, X., Bohm, A. \& Kim, S.-H. (1994). High-resolution crystals and preliminary X-ray diffraction studies of a catalytic RNA. Acta Crystallog. sect. D, 50, 290-292.

Pley, H. W., Lindes, D. S., DeLuca-Flaherty, C. \& McKay, D. B. (1993). Crystals of a hammerhead ribozyme. J. Biol. Chem. 268, 19656-19658.

Pley, H. W., Flaherty, K. M. \& McKay, D. B. (1994). Threedimensional structure of a hammerhead ribozyme. Nature, 372, 68-74.

Schultz, S. C., Shields, G. C. \& Steitz, T. A. (1990). Crystallization of Escherichia coli catabolite gene activator protein with its DNA binding site. J. Mol. Biol. 213, 159-166.

Scott, W. G., Finch, J. T. \& Klug, A. (1995). Crystal Structure of an all-RNA hammerhead ribozyme. Cell, in the press.

Symons, R. H. (1992). Small catalytic RNAs. Annu. Rev. Biochem. 61, 641-671.

Uhlenbeck, O. C. (1987). A small catalytic oligoribonucleotide. Nature, 328, 596-600.

Edited by T. Richmond

(Received 26 January 1995; accepted 21 April 1995) 